Artigo Original

Hegemonia - Revista Eletrônica do Programa de Mestrado em Direitos Humanos, Cidadania e Violência/Ciência Política do Centro Universitário Unieuro

ISSN: 1809-1261

UNIEURO, Brasília, número 27 (Especial), 2019, pp. 215-244.

Recebido em: 16/9/2018

Avaliado em: 27/10/2018

Aprovado em: 26/11/2018

\title{
WHY IS EDUCATIONAL RESILIENCE IMPORTANT? HIGHER EDUCATION IN MARGINALIZED POPULATIONS IN MEXICO CITY
}

Rosa Ynés Alacio García ${ }^{1}$

Abstract: Educational resilience is studied in a capability poverty and marginalization context; it is an emotional component that intervenes in effective decision-making and has an impact on the academic lives of students. The concepts of "capability poverty" and "marginalization" are defined from a multidisciplinary standpoint, and educational resilience is used to pinpoint the importance of the emotional component in the fulfillment of academic achievement. Data was extracted from three surveys performed in 2005, 2010 and 2015 respectively; four student groups were selected through participant observation; case selection was performed again to apply a questionnaire encompassing expectations, motivations, experiences and academic results. Resilience is observed in university graduation processes, as it contributes to a feeling of selfworth and competence development when writing a dissertation and defending it using academic language.

Key Words: marginalization, capability poverty, educational resilience, emotional component, decision making, self-worth.

Resumen: Se estudia la resiliencia educativa, en situación de pobreza de capacidades y marginalidad, como componente emocional que interviene en la efectiva toma de decisiones, impactando la vida académica de los estudiantes. Desde una construcción conceptual transdisciplinaria se definen los conceptos, pobreza de capacidades y marginalidad, y se utiliza la categoría resiliencia educativa, para ubicar la importancia del componente emocional en el cumplimiento de logros académicos universitarios. Se toman los datos de tres encuestas aplicadas en 2005, 2010 y 2015, se selecciona a cuatro grupos de estudiantes con la técnica de la observación participante, y se vuelve a realizar una selección de casos para aplicar un cuestionario que aborda expectativas, motivaciones, experiencias y resultados académicos. Se observa la resiliencia para titularse, abonando a sentimientos de valía personal, desarrollo de competencias para redactar un escrito original de autoría propia, y defenderlo utilizando un lenguaje académico. Palabras-claves: marginalidad, pobreza de capacidades, resiliencia educativa, componente emocional, toma de decisión, valía personal.

\footnotetext{
${ }^{1}$ Doctor of Social Studies and professor of Autonomous University of Mexico City.
} 
Artigo Original

Hegemonia - Revista Eletrônica do Programa de Mestrado em Direitos Humanos, Cidadania e Violência/Ciência Política do Centro Universitário Unieuro

ISSN: $1809-1261$

UNIEURO, Brasília, número 27 (Especial), 2019, pp. 215-244.

Introduction and Method

Capability poverty consists in intrinsically important deprivations (Sen, 2000: 115). Poverty can have an emotional component that impacts academic life. How is the impact of educational resilience observed in higher education? Resilience is understood as the ability to cope with adverse situations, deal with tough circumstances, and overcome significant difficulties while learning from them and being transformed by adversity, which no one can really escape from (Baruch and Stutman, 2008: 61; Henderson, 2008: 18). I suggest the educational resilience concept, as the emotional capacity to choose the achievement of a college degree, from the submission of an own authorship essay, overcoming the marginalized population capabilities poverty.

Educational resilience seen as the emotional skill to obtain a degree through the creation and defense of a dissertation nourishes self-worth and professional worth, despite the poverty and marginalization situation. The study analyzes students from Universidad Autónoma de la Ciudad de México (UACM, Autonomous University of Mexico City), who are selected for enrollment into higher education programs by draw.

Educational resilience is studied in a capability poverty and marginalization context; it is an emotional component that intervenes in effective decision-making and has an impact on the academic lives of students. The concepts of "capability poverty" and "marginalization" are defined from a multidisciplinary standpoint, and educational resilience is used to pinpoint the importance of the emotional component in the fulfillment of academic achievement. Resilience is observed in university graduation processes, as this contributes to a feeling of self-worth and competence development when writing a dissertation and defending it using academic language. 
Hegemonia - Revista Eletrônica do Programa de Mestrado em Direitos Humanos, Cidadania e Violência/Ciência Política do Centro Universitário Unieuro

ISSN: $1809-1261$

UNIEURO, Brasília, número 27 (Especial), 2019, pp. 215-244.

Three data collection techniques were utilized: surveys applied to incoming freshmen in school years 2005, 2010 and $2015^{2}$, participant observation, and a questionnaire applied to a selection of students ${ }^{3}$.

How is educational resilience observed in academic achievement in higher education? Educational resilience is the emotional component that determines constant clarity in professional goals, the progress made on academic achievement during the dissertation process, and the reaffirmation of self-worth as a professional, overcoming adverse situations related to marginalization and capability poverty.

The fundamental element of educational resilience is the adequate handling of emotions, whereas the secondary element is goal-centered decision making; personal decisions that lead to overcoming obstacles strengthen self-worth from the 'I have', 'I am', and 'I can' categories.

The 'I have', 'I am', and 'I can' categories have been developed by Henderson (2008: 28), and the concept of self-worth as an element for acquiring capabilities and strengths to face adversity by Baruch and Stutman (2008: 68-69).

\section{I) Theoretical Framework}

Poverty is multidimensional (Mora, 2010: 12-13). Poverty occurs when "subjects face severe deprivations to their welfare", so based on multiple social schemes, poor families must live their lives with social restrictions that prevent them from covering needs such as housing, health, food, education, recreation, social participation and political participation (Mora, 2010: 13-14).

\footnotetext{
2 The database was generated by the Academic Service Coordination of UACM. Information was provided for this text.

3 The author of this paper has known the students' profile since 2007, after a wide number of interviews held informally in the San Lorenzo Tezonco, Del Valle, and Cuautepec campuses, as well as twice in the Casa Libertad campus.
} 
Artigo Original

Hegemonia - Revista Eletrônica do Programa de Mestrado em Direitos Humanos, Cidadania e Violência/Ciência Política do Centro Universitário Unieuro

ISSN: $1809-1261$

UNIEURO, Brasília, número 27 (Especial), 2019, pp. 215-244.

Poverty is the lack of income and the lack of capabilities (Sen, 2000: 117). Capability poverty consists in "intrinsically important deprivations", while income poverty refers to relevant instrumental deprivations (114 and 117). Poverty, as defined by Amartya Sen, "corresponds to a certain degree of deprivation that impedes full development of abilities and freedom to have and be whatever a person rationally considers is worth having or being" (Mora, 2010: 17).

Poverty overlaps with marginalization events and happens mainly in the outskirts of cities. Outskirts are "complex spaces" where diverse social differentiation processes and "forms of city production" take place, together with the existence of different social agents, life and ownership forms with specific land expansion and occupation characteristics (Isunza and Méndez, 2011: 115). The "irregular incorporation of peripheral lands for low-income housing through self-build projects" has typified the change from common tenancy to private ownership due to location, legal irregularities, and little or no infrastructure (Duhau and Cruz, quoted by Isunza and Méndez, 2011: 115). Peripheral areas are known for their urban discontinuity and rural lifestyle (Isunza and Méndez, 2011: 117).

Marginality and marginalization are two different concepts; "marginality resides in individuals", whereas marginalization resides in geographic entities, as opposed to economic marginalization, which centers on production relationships (Cortés, 2006: 73). The marginalization index developed by the Mexican National Population Council (CONAPO) measures the population's deprivations in relation to the access to basic services of education, housing and income; nonetheless, the indicator lays out the localities' characteristics, not the individuals' (Cortés, 2006: 75). In contrast, with the current way of measuring marginalization, marginality supposes a limitation to the values and behavior of modern man (Cortés, 2006: 75).

The marginality concept refers to individuals who move in five dimensions: a) ecologic dimension, b) socio-psychological dimension, c) sociocultural dimension, d) economic dimension, and e) political dimension (Desal 1965, quoted in Cortés, 2006: 75-76). The main characteristics are the following: these people live in deteriorated dwellings located in "misery 
Artigo Original

Hegemonia - Revista Eletrônica do Programa de Mestrado em Direitos Humanos, Cidadania e Violência/Ciência Política do Centro Universitário Unieuro

ISSN: $1809-1261$

UNIEURO, Brasília, número 27 (Especial), 2019, pp. 215-244.

circles"; they are sub-proletarians who have subsistence and unstable jobs; they do not participate in responsibility tasks to solve social problems, including their own; "their groups lack internal integration", they have low educational, cultural, health, housing and life levels and a limited capacity to act, making them merely "inhabitants of the place" (Desal 1965, citado en Cortés, 2006: 76). (Desal 1965, quoted in Cortés, 2006: 76). On the other hand, economic marginalization puts its research focus on production relationships and not individuals. The difference is quite substantial. While the first one wagers on the change of mindset, the second on wages on their incorporation to central production relationships (Cortés, 2006: 76).

Yet another approach uses marginalization and marginality to describe individuals who "are not integrated in the wealth and social recognition production networks" (Massé 1965, Lenoir 1974 quoted in Cortés, 2006: 77). The fact is that confusing marginalization data with marginality leads to ecological fallacies (King 1997, quoted in Cortés, 2006: 80). What is more, social exclusion encompasses different ritualized elements that "remit to a judgment articulated by an official court, relying on sets of rules and calling up constituted entities" (Castel 1998 quoted in Cortés, 2006: 77). The social inclusion/exclusion concept is included from the social rights standpoint: formal citizen participation, social and employment protection, and access to social capital (Minujin 1998, quoted in Cortés, 2006: 78). Despite the contrast in their approach, both economic marginalization and marginality "have clear links to social exclusion" (Cortés, 2006: 81). Another conceptual difference sustains that "the marginality theory resorts to the nation of social networks (Lomnitz, 1975 in Cortés, 2006: 81), while exclusion utilizes the social capital concept" (Cortés, 2006: 81).

Historically, exclusion in Europe happened after undergoing inclusion processes; in Latin America "there are still sectors of the population that have never been either included of excluded" (Cortés, 2006: 82). In the face of social exclusion processes, educational resilience works as an emotional thrust mechanism against adversity, which results are seen in academic life. 
Artigo Original

Hegemonia - Revista Eletrônica do Programa de Mestrado em Direitos Humanos, Cidadania e Violência/Ciência Política do Centro Universitário Unieuro

ISSN: $1809-1261$

UNIEURO, Brasília, número 27 (Especial), 2019, pp. 215-244.

Resilience is the human potential and ability to cope with adverse situations, deal with tough circumstances, and overcome significant difficulties while learning from them and being transformed by adversity, which no one can really escape from (Baruch and Stutman, 2008: 61; Henderson, 2008: 18). The potential that allows "building the necessary strengths to tackle adversity and overcome obstacles" is known as resilience; it is made up by yin and yang (Baruch and Stutman, 2008: 61). Yin is developed in childhood, when a child gets love, devotion and care from an adult who treasures him/her. Yang is the dose of adversity we face, which leads us to developing resilience. Nonetheless, "the lack of either makes the other one inefficient and even harmful" (Baruch and Stutman, 2008: 59-60).

Henderson places the elements necessary to develop resilience in a child, youth or adult in the development of trust, autonomy, application, identity, intimacy, integrity and ability to generate (2008: 22-23). In the case of youths and adults it is fundamental to identify "which resilient factors have already been developed" (Henderson, 2008: 23). Application is the ability to take a task forward" (Henderson, 2008: 28).

The 'I have' (external support), 'I am' (inner strength) and 'I can' (interpersonal and problemsolving skills) categories allow disaggregating the development of the resilience capability in youths and adults; hence, these categories in the application element allow tracking the 'I have', as well as the independence and importance of having role models concepts. As for the 'I am' category, the main elements are goal achievement, clarity for planning the future, and ability to be held responsible for your actions. Lastly, 'I can' encompasses “committing to a task all the way to its completion, solving problems and asking for help when in need" (Henderson, 2008: 28). Feeling valuable helps in the development of capabilities and increase of strengths before adversity (Baruch and Stutman, 2008: 68-69).

I bring these categories back, to set a statement on the importance of educational resilience from the visualization of these components in the personal decision making, that allows to overcome the capabilities poverty from the educational discipline, and the value of transforming their professional nowadays, overcoming adverse contexts. I sustantiate the importance of the 
Artigo Original

Hegemonia - Revista Eletrônica do Programa de Mestrado em Direitos Humanos, Cidadania e Violência/Ciência Política do Centro Universitário Unieuro

ISSN: $1809-1261$

UNIEURO, Brasília, número 27 (Especial), 2019, pp. 215-244.

emotional component, and the personal decision making to recognize the obstacles and to overcome them, from the ability to hold what they have now, allowing them to decide a new professional life path. I present the educational resilience as the understaning of ME and its circumstances from the self-responibility, and the decision to build a new life path, accepting the family history, and deciding to take another professional direction.

II) Institution and Student Characteristics

The Universidad de la Ciudad de México (UCM) was founded on April 26, 2001 as an educational model accessible to citizens, namely "residents coming from disadvantaged sectors of Mexico City" (articles 1 and 3 of the Decree published in the Mexico City Official Gazette). UCM changed its name to Universidad Autónoma de la Ciudad de México (UACM) on January 5, 2005 to continue its efforts to address the population that has been excluded from higher education models in Mexico City (Universidad Autónoma de la Ciudad de México Law, 2013: 3 and 17$)$, refer to Table 1. 
Hegemonia - Revista Eletrônica do Programa de Mestrado em Direitos Humanos, Cidadania e Violência/Ciência Política do Centro Universitário Unieuro

ISSN: $1809-1261$

UNIEURO, Brasília, número 27 (Especial), 2019, pp. 215-244.

Table 1

Educational Offerings

\begin{tabular}{|c|c|c|c|}
\hline Axis & Humanities and Social Sciences & $\begin{array}{ll}\text { Science } & \text { and } \\
\text { Humanities } & \end{array}$ & Science and Technology \\
\hline $\begin{array}{l}\text { Bachelor's } \\
\text { Degrees }\end{array}$ & $\begin{array}{l}\text { 1. Art and Cultural Heritage } \\
\text { 2. Political Sciences and Urban } \\
\text { Administration } \\
\text { 3. Social Sciences } \\
\text { 4. Communication and Culture } \\
\text { 5. Literary Creation } \\
\text { 6. Philosophy and History of } \\
\text { Ideas } \\
\text { 7. History and Modern Society } \\
\text { 8. Law }\end{array}$ & $\begin{array}{l}1 \text { Environmental } \\
\text { Sciences and } \\
\text { Climate Change } \\
2 \text { Health and } \\
\text { Nutrition } \\
3 \text { Health Promotion } \\
4 \text { Civil Protection } \\
\text { and Risk } \\
\text { Management }\end{array}$ & $\begin{array}{l}1 \text { Genomic Sciences } \\
2 \text { Systems Engineering and } \\
\text { Urban Transportation } \\
3 \text { Electronic Industrial } \\
\text { Systems Engineering } \\
4 \text { Software Engineering } \\
5 \text { Electronic Systems and } \\
\text { Telecommunications } \\
\text { Engineering } \\
6 \text { Energy Systems } \\
\text { Engineering } \\
7 \text { Mathematic Modeling }\end{array}$ \\
\hline $\begin{array}{l}\text { Postgraduate } \\
\text { Studies }\end{array}$ & $\begin{array}{l}1 \text { Master's Degree in Human } \\
\text { Rights Defense and Promotion } \\
2 \text { Master's Degree in Social } \\
\text { Sciences }\end{array}$ & $\begin{array}{l}1 \text { Master's Degree in } \\
\text { Complexity } \\
\text { Sciences } \\
2 \text { Master's Degree in } \\
\text { Environmental } \\
\text { Education } \\
3 \text { City Studies }\end{array}$ & $\begin{array}{l}1 \text { Master and PhD in } \\
\text { Genomic Sciences } \\
2 \text { Master's Degree in } \\
\text { Renewable Energy Sources } \\
3 \text { Master's Degree in Energy } \\
\text { Engineering }\end{array}$ \\
\hline
\end{tabular}

Source: http://www.uacm.edu.mx/ Educational Offering. Inquiry performed on July 92016. The table was prepared by the author.

The university has five campuses that offer on-site classes; three of them are located in the outskirts: Casa Libertad, Cuautepec and San Lorenzo Tezonco (UACM Database), which are areas with a high and very high level of marginalization ${ }^{4}$ (SIDESO Database, 2000).

The Mexico City population displays strong social and economic contrasts; this is reflected on the wide variety of ways of populating the territory. UACM addresses the population that has been excluded from other university models and has certain limitations to enroll in

\footnotetext{
${ }^{4}$ Iztapalapa has 1791672 inhabitants, and Gustavo A. Madero 1173 152, first and second place in population density in Mexico City (CONAPO, 2010: 171). The CONEVAL states that Iztapalapa holds the second place in poverty, while Gustavo A. Madero is in tenth place, considering the national situation analysis (CONEVAL, 2011: 25).
} 
Artigo Original

Hegemonia - Revista Eletrônica do Programa de Mestrado em Direitos Humanos, Cidadania e Violência/Ciência Política do Centro Universitário Unieuro

ISSN: $1809-1261$

UNIEURO, Brasília, número 27 (Especial), 2019, pp. 215-244.

higher education studies. A considerable percentage of this population is known for having little clarity in establishing a professional life path.

III) Academic Services Data

UACM has matriculated 13 generations and a total of 42,892 students from 2001 and 2015. Out of this group of students, 770 are in prison, and 42,122 have attended the campuses; age varies between 18 and 60 years ${ }^{5}$. Enrollment into the model is by draw ${ }^{6}$. Until 2015, the number of graduates added up to 931 for Bachelor's Degree and 175 for Postgraduate Studies. 1065 students completed all credits and 120 started the process to obtain their Certificate of Completion of Studies.

The first generation to enter UCM consisted of 596 students in 2001. In 2005 enrollment from prison was offered for the first time. The Student Services Coordination (CSE in Spanish) has performed studies on the student's profile to identify this population's characteristics.

For research purposes, we took the socioeconomic data and health certificates generated by CSE for 2005, 2010, and 2015. The question form has changed; consequently, information that enables comparison has been included (See Table 2).

\footnotetext{
5 Thanks to the UACM Enrollment and Certification department for providing the information.

${ }^{6}$ Facilities include a low-cost cafeteria. Students have access to free medical attention,
} 


\section{Artigo Original}

Hegemonia - Revista Eletrônica do Programa de Mestrado em Direitos Humanos, Cidadania e Violência/Ciência Política do Centro Universitário Unieuro

ISSN: $1809-1261$

UNIEURO, Brasília, número 27 (Especial), 2019, pp. 215-244.

Table 2

Enrollment Registration and Sample Size ${ }^{7}$

\begin{tabular}{|c|c|c|c|}
\hline & 2005 & 2010 & 2015 \\
\hline Enrollment Registration & 3751 & 2736 & 3966 \\
\hline Sample Size & $1562(41.64 \%)$ & $2625(95.94 \%)$ & $2626(66.21 \%)$ \\
\hline
\end{tabular}

Source: Student Services Coordination. Texts: UACM 2005-I, 2010 Students Profile and database 2015. The table was prepared using the UACM Enrollment and Student Services data.

Monthly family income was asked in all questionnaires ${ }^{8}$. Income of 6000 pesos or less per family: $63.70 \%$ (75.74\% in 2005; 68.28\% in 2010; and 68.28 in 2015). Regarding range allocation of minimum wage, Mexico City belongs to geographical region A, the highest in comparison to other areas (STPS, 2016a). In 2005 minimum wage was 45.24 pesos, in 2010 it was 57.46 pesos, and in 2015 it was 70.10 pesos (STPS, 2016b).

Another question seen in all three questionnaires was the level of educational attainment of parents. This information reflects academic support in the immediate circle of students who attend UACM. See Table 3.

\footnotetext{
${ }^{7}$ Information from prison is not considered.

${ }^{8}$ Answers could be untrue due to the interest of getting a scholarship.
} 
Hegemonia - Revista Eletrônica do Programa de Mestrado em Direitos Humanos, Cidadania e Violência/Ciência Política do Centro Universitário Unieuro

ISSN: 1809-1261

UNIEURO, Brasília, número 27 (Especial), 2019, pp. 215-244.

Table 3

Unfinished high school, complete secondary school or lower level of education

\begin{tabular}{|c|c|c|c|}
\hline & 2005 & 2010 & 2015 \\
\hline Father & $66.06 \%$ & $73.15 \%$ & $55.23 \%$ \\
\hline Mother & $75.29 \%$ & $77 \%$ & $67.1 \%$ \\
\hline
\end{tabular}

Source: Student Services Coordination. Texts: UACM 2005-I, 2010 Students Profile and database 2015. The table was prepared using the UACM Enrollment and Student Services data.

Regarding motivation to study, what students mean by 'personal growth' is unknown; however, this answer had the highest percentage in all three questionnaires. See Table 4.

Table 4

Reasons why you continue studying

\begin{tabular}{|l|c|c|c|}
\hline & 2005 & 2010 & 2015 \\
\hline Personal growth & & & \\
& $91.42 \%$ & $78.37 \%$ & $93.6 \%$ \\
\hline
\end{tabular}

Source: Student Services Coordination. Texts: UACM 2005-I, 2010 Students Profile and database 2015. The table was prepared using the UACM Enrollment and Student Services data.

As for the optimal study conditions question, the 2005 questionnaire identified the tools and support students had to perform academic work; in 2010 the existence of a physical space to study was prioritized, whereas in 2015 , the question focused on having a proper environment for studying in quietness. Answers changed based on the questions' wording. 
Hegemonia - Revista Eletrônica do Programa de Mestrado em Direitos Humanos, Cidadania e Violência/Ciência Política do Centro Universitário Unieuro

ISSN: $1809-1261$

UNIEURO, Brasília, número 27 (Especial), 2019, pp. 215-244.

Table 5

Academic Activities

\begin{tabular}{|l|c|c|c|}
\hline & 2005 & 2010 & $2015^{9}$ \\
\hline Yes & & & \\
\hline No & $82.91 \%$ & $100 \%$ & $5.02 \%$ \\
\hline
\end{tabular}

Source: Student Services Coordination. Texts: UACM 2005-I, 2010 Students Profile and database 2015. The table was prepared using the UACM Enrollment and Student Services data.

The question on the number of attempts to enroll in some sort of university educational model was included in the 2010 and 2015 questionnaires.

Table 6

Number of attempts to enroll in another university or institution

\begin{tabular}{|c|c|c|}
\hline & 2010 & 2015 \\
\hline None & $27.84 \%$ & $32.15 \%$ \\
\hline One attempt & $22.32 \%$ & $32.41 \%$ \\
\hline Two attempts & $18.62 \%$ & $23.50 \%$ \\
\hline Three attempts & $12.49 \%$ & $10.59 \%$ \\
\hline
\end{tabular}

Source: Student Services Coordination. Texts: UACM 2005-I, 2010 Students Profile and database 2015. The table was prepared using the UACM Enrollment and Student Services data.

The set of questions has varied. In 2005, questions centered on the material features in the student's physical environment (housing, work, income, study conditions, dietary habits, illnesses or ailments), their family conditions, transportation facilities, type of activities performed, physical health. The survey did not include the number of attempts to enroll in a University (UACM, 2005).

The questionnaire designed for the incoming freshmen students of 2010 included greater data on the population surveyed, such as previous unfinished degrees and causes of dropout; the

9 12.68\% answered 'sometimes', and 9.60\% did not answer (UACM, 2015). 
Artigo Original

Hegemonia - Revista Eletrônica do Programa de Mestrado em Direitos Humanos, Cidadania e Violência/Ciência Política do Centro Universitário Unieuro

ISSN: $1809-1261$

UNIEURO, Brasília, número 27 (Especial), 2019, pp. 215-244.

survey also delved into their family information and information on how they use their spare time, what their motivations and barriers for studying are, greater information on health, specifically sleeping habits, family health history, phobias, allergies, disabilities, treatments

received and medicaments used for emotional issues. Only two questions focused on the motivations and barriers to "continue studying" (UACM, 2010). The 2015 questionnaire centered on emotional health aspects such as communication, parents affection and family acknowledgement (UACM, 2015).

IV) Case Selection Results

This analysis recovers sixteen experiences from graduated and non-graduated students in different age groups and with different enrollment conditions. The groups were designed based on three selection criteria: 1) Knowledge of their life history, 2) Knowledge of their academic path, and 3) Mentoring during their study years in university.

At the moment of the interview Students had completed or were about to complete their Bachelor's Degree in Political Science and Urban Administration in the Cuautepec and San Lorenzo Tezonco campuses. The study dimensions considered were: socioeconomic level, motivation to study, expectations, experience as students, and academic results. The purpose of the applied questionnaire was to identify the educational resilience ability in each participant. Groups were organized based on their academic result similarities. The first group included students with dissertation project in process; the second one grouped graduates, dropout students and students having trouble with their dissertation project; the third group consisted in adults attending university at that time, who had interrupted their academic path for years or who had other studies; the fourth group gathered graduates who defended a dissertation of their own authorship. 
Artigo Original

Hegemonia - Revista Eletrônica do Programa de Mestrado em Direitos Humanos, Cidadania e Violência/Ciência Política do Centro Universitário Unieuro

ISSN: $1809-1261$

UNIEURO, Brasília, número 27 (Especial), 2019, pp. 215-244.

Table 7

Groups in Qualitative Study

\begin{tabular}{|c|c|c|c|}
\hline $\begin{array}{c}\text { Group } 1 \\
\text { Graduates (Dissertation } \\
\text { in Process) }\end{array}$ & $\begin{array}{l}\text { Group } 2 \\
\text { Graduates (not } \\
\text { certified) }\end{array}$ & $\begin{array}{c}\text { Group } 3 \\
\text { Adults in College }\end{array}$ & $\begin{array}{c}\text { Group } 4 \\
\text { Graduates (certified } \\
\text { with degree) }\end{array}$ \\
\hline $\begin{array}{c}51 \text { years }(\text { Three } \\
\text { children) } \\
27 \text { years (no children) } \\
27 \text { years (no children) }\end{array}$ & $\begin{array}{l}28 \text { years (no } \\
\text { children) } \\
28 \text { years (no } \\
\text { children) } \\
26 \text { years (no } \\
\text { children) } \\
30 \text { years (two } \\
\text { children) }\end{array}$ & $\begin{array}{l}50 \text { years (three } \\
\text { children) } \\
48 \text { years (two } \\
\text { children) } \\
41 \text { years (four } \\
\text { children) }\end{array}$ & $\begin{array}{c}28 \text { years (no children) } \\
26 \text { years (no children) } \\
35 \text { years (no children) } \\
28 \text { years (no children) } \\
25 \text { years (no } \\
\text { children) }{ }^{10} 57 \text { years } \\
\text { (one daughter) }^{11}\end{array}$ \\
\hline
\end{tabular}

Source: Prepared by author.

The questions were divided into three blocks. The first block focused on the past, with questions as: Why did you decide to study in UACM? Was UACM your first option? What did you do before joining UACM? Did you leave school for some time? What stopped you from studying before? The second block addressed the future. Participants had to answer to the question: How do you see yourself in five years? The third block related to the present: What are you doing to get your degree? Answers are significant and indicative of action, lack of action, and the ability to adapt to different and/or adverse circumstances.

\section{Questions in Block 1:}

\section{Group 1:}

"UACM was my third option. I was going from one workshop to another; I was a frustrated mother and wife because I did not had the chance to continue my education, so I decided to finish high school to be able to help my children. When I finished high school I decided to continue to higher education. I joined UACM because admission was not determined by examination; besides the project is good, it is made for people who really want to study. Yes, my

\footnotetext{
${ }^{10}$ This student was in group 1; however, by the end of school year 2016-II she successfully defended her dissertation. When working to have her presentation ready, she strengthened the feeling of believing in herself: self-confidence and presence in an academic environment. Groups have not changed since the moment in which the interview was made, and until September 2018.

11 This student was in group 3, however, by the 2017-I semester, he successfully defended his dissertation.
} 
Artigo Original

Hegemonia - Revista Eletrônica do Programa de Mestrado em Direitos Humanos, Cidadania e Violência/Ciência Política do Centro Universitário Unieuro

ISSN: $1809-1261$

UNIEURO, Brasília, número 27 (Especial), 2019, pp. 215-244.

education was interrupted. I completed elementary school as a child. Afterwards, I wanted to go to secondary school but we were 10 siblings and my parents were peasants, so they could not afford to send us all to school. When I was a teenager I got into a night school program for people who worked during the day, so I completed secondary education. Then I got married and when I already had my three children I regretted that I could not help them with their homework. So that is when I decided to go back to school. I wanted to be able to help my kids, but more importantly, I wanted to prove them that anything is possible. They used to tell me that I did not understand them because I did not know how tough studying became the higher you got. So I plucked up the courage to talk to my husband and told him I would go back to high school to be able to support our children. It was not easy to convince him, but that is how I started this project I am about to finish.” Graduate, dissertation in process. 51 years old.

"I stopped studying for two years because I did not make it into my first options. Before joining UACM, I was learning craftworks and English in ESCA Tepepan. I enrolled to those courses because I did not want to interrupt my education completely." Graduate, dissertation in process. 27 years old.

"UACM was not my first option. I stayed because I went to the No.1 G.A.M "Belisario Domínguez" High School, which is part of IEMS (Institute of High School Education) and supposedly students coming from those schools were given preference to join UACM. I never stopped studying. Having a college degree will allow me to have better life quality, because by being a professional you aspire to a better wage, which translates into less deprivations. Besides I can be independent." Graduate, dissertation in process, 27 years old.

\section{Group 2:}

"It was not my first option. I stopped studying for a year, UACM was the option I got." Graduate, 28 years old.

"No, it was my second option; the first one was UAM. I paused for three years, work did not leave me time for studying and I did not make it into my first option. As a matter of fact, during 
Artigo Original

Hegemonia - Revista Eletrônica do Programa de Mestrado em Direitos Humanos, Cidadania e Violência/Ciência Política do Centro Universitário Unieuro

ISSN: $1809-1261$

UNIEURO, Brasília, número 27 (Especial), 2019, pp. 215-244.

the first semester I truly could not believe than an institution had taken me. I also had to interrupt my education for some time in UACM, because of financial issues and personal events (some relatives passed away). I dropped out for a year; this lessened the habits I had already acquired. More than getting a degree is a goal you set for yourself. In my case, I am the only one in my family who continued studying, and I expect to keep on.” Graduate, 28 years old.

"Yes, it was my first option. Coming from a government high school, I had preferred access to it. During the career I had to dropout because of family issues. I had to start working and I could not work and study at the same time." Student, 26 years old.

"No, I had already enrolled to another university in Morelos before. The decision to go to UACM was due to several factors; it was closer to my home, I did not have to pay for it, and most importantly, I got really interested in the Political Sciences and Urban Administration Degree. That is why I decided to go to UACM. I dropped out for three years; I had to start working because my first child was born. I worked in a carpentry workshop. I believe that having a career gives me the opportunity to have a better job.” Graduate, 30 years old.

\section{Group 3:}

"I was working. UACM was my first option. I dropped out because I have to provide for my family. I study for personal, work, and cultural growth.” Adult in college, 50 years old.

"It was not my first option. I heard about its existence by chance and I immediately saw it as an opportunity. I was working." Adult in college, 48 years old.

"It was my first option. I like the support teachers provide to students. I dropped out, yes. Where I grew up, there was no motivation for studying and it was not financially feasible. Before joining this university I was studying high school and working." Adult in college, 41 years old. 
Artigo Original

Hegemonia - Revista Eletrônica do Programa de Mestrado em Direitos Humanos, Cidadania e Violência/Ciência Política do Centro Universitário Unieuro

ISSN: $1809-1261$

UNIEURO, Brasília, número 27 (Especial), 2019, pp. 215-244.

Group 4:

"It was not my first option. I was working. I interrupted for a year, because I did not get into my first option. Yes, I have studied a master's degree and I plan on getting a PhD." Graduate (certified with degree), 28 years old ${ }^{12}$.

"UACM was my second option. I never stopped; I was in the IEMS high school before. I decided to join because I found the educational model attractive and innovative." Graduate (certified with degree), 26 years old ${ }^{13}$.

"It was not my first option. Yes, I paused for some time because I got married and pregnant after junior high, so studying was not in my plans. Besides, I did not have the financial means to afford it. In 2007 IEMS offered me the chance to continue with my academic life. I became a high school student at the Mexico City Secondary School Institute. Because UACM's educational model allowed me to study at my own pace without putting aside my other obligations at work and at home, as I am a single-parent now. Besides the campus is close to my home, so it was easy for me to adapt to my different roles. I got my degree on May 18, 2016, after two years of having completed all credits. Now my plan is to enroll into a Master's Degree program.” Graduate (certified with degree), 35 years old.

"No. I did not even know about this college. I was attending high school in Oaxaca. But because of the violence in the state we moved to Mexico City, where I sought to continue studying. It was the only university that was still open for enrollment, so I investigated more about its work and decided to submit by papers for the draw. So when I finished high school I moved here with my family, escaping from the violent context in my community. But I did not stop studying. At the beginning I did not understand all the texts. They were very technical and my Spanish was not all that fluent, so that made reading hard. When I graduated, it took me six months to get

\footnotetext{
12 This student is currently a $\mathrm{PhD}$ Candidate; he has participated in research groups and has publications in several magazines. He lives in Ecatepec, a municipality with a high crime rate.

13 IEMS stands for Mexico City Institute for Secondary Education. All students there can go directly to UACM.
} 
Hegemonia - Revista Eletrônica do Programa de Mestrado em Direitos Humanos, Cidadania e Violência/Ciência Política do Centro Universitário Unieuro

ISSN: $1809-1261$

UNIEURO, Brasília, número 27 (Especial), 2019, pp. 215-244.

the degree. Then I studied a Master's Degree in Human Rights and Education for Peace in the National University of Costa Rica. I got a scholarship from CONACYT-CIESAS and the National Commission for the Development of the Indigenous Peoples." Graduate (certified with degree), 28 years old.

"I was in high school. UACM was my first choice because from IEMS you could go directly into that college and I wanted to continue my education. I had an accident and dropped out for a year.” Graduate (certified with degree), 25 years old.

“It was my first option, although before I went to the IPN's Economics School. I dropped out because of my work schedule”. Before joining I was working.” Adult in college, 57 years old.

Block 2. How do you see yourself in five years?

Group 1:

"Working in the Public Administration and having a Master's Degree." Graduate with dissertation in process, 51 years old.

"I just got married, so I imagine having a healthy family, a good stable job and a business of my own." Graduate with dissertation in process, 27 years old ${ }^{14}$.

"Independent, with a stable job and a child. Planning new projects to improve my home and traveling to unknown places." Graduate with dissertation in process, 27 years old.

${ }^{14} \mathrm{He}$ divorced six months later. He has had several jobs as an intern. He lives in Magdalena Contreras and performs research on irregular settlements in Los Dinamos, Colonia Carbonera. His certification documents are retained, despite having started the process in the degree certification office. The student has nos made the changes suggested by the reviewers. 
Artigo Original

Hegemonia - Revista Eletrônica do Programa de Mestrado em Direitos Humanos, Cidadania e Violência/Ciência Política do Centro Universitário Unieuro

ISSN: $1809-1261$

UNIEURO, Brasília, número 27 (Especial), 2019, pp. 215-244.

Group 2:

“Traveling, studying working." Graduate, 28 years old.

"In a better job position, maybe giving classes at high school level, with a Master's Degree and working in the Public Administration." Graduate, 28 years old.

"With my degree and in a better job, resting and enjoying." Student, 26 years.

"Having finished my degree, with a better wage and maybe studying a master's. At least that is what I hope." Graduate, 30 years old.

Group 3:

"Satisfied with my achievement." Adult in college, 50 years old.

"Giving classes in an educational institution, having finished my master's degree and in a PhD." Adult in college, 48 years old.

"Having completed my master's and enrolled in a PhD program; and of course, having a higher level of knowledge than the one I currently have." Adult in college, 41 years old.

Group 4:

"Consolidated as a social scientist." Graduate (certified with degree), 28 years old.

"Yes, of course I am planning on doing a Master's Degree, but I cannot do it right now for personal reasons. I work right now, but in five years I see myself working in something I really enjoy (more than now) and being proficient in English. Probably living in some other country." Graduate (certified with degree), 26 years old. 
Hegemonia - Revista Eletrônica do Programa de Mestrado em Direitos Humanos, Cidadania e Violência/Ciência Política do Centro Universitário Unieuro

ISSN: 1809-1261

UNIEURO, Brasília, número 27 (Especial), 2019, pp. 215-244.

"I hope that I will have been admitted to a $\mathrm{PhD}$ and have a fix job that will let me continue supporting my girls so that they continue studying." Graduate (certified with degree), 35 years old.

"Having a PhD and working in a decision-making space to build inclusive actions for our society." Graduate (certified with degree), 28 years old.

“Having obtained my degree and studying a master's degree. Also, having a job that allows me to make some ambitions come true." Graduate (certified with degree), 25 years old.

"Getting a promotion in the Public Administration." Adult in college, 57 years old.

Block 3 What are you doing to get your degree?

Group 1:

"I am waiting for the reviewers to read my thesis and make observations and approve it." Graduate (Dissertation in Process), 51 years old.

"I keep preparing myself, acquiring experience and trying to fulfill the requirements to be 100\% certified." Graduate (Dissertation in Process), 27 years old.

"It took me approximately four years to complete all credits. Now I am waiting for the readers to approve my dissertation." Graduate (Dissertation in Process), 27 years old.

\section{Group 2:}

"I am trying to finish my dissertation. I work, but I want to get to the finish line." Graduate (Dissertation in Process), 28 years old. 
Artigo Original

Hegemonia - Revista Eletrônica do Programa de Mestrado em Direitos Humanos, Cidadania e Violência/Ciência Política do Centro Universitário Unieuro

ISSN: $1809-1261$

UNIEURO, Brasília, número 27 (Especial), 2019, pp. 215-244.

"I have not gotten the degree. I am missing only one course, Seminar II. Several factors come into play, but mainly, I know I should stop working to focus on this course. I need to absorb that I only have one more step to go (the thesis). It is just a matter of approaching a professor who will advice me and urge me to get things done. I want that professor to not give me one break, cause fortunately or unfortunately, I do not like to be bossed around, but I need someone who will push me to accomplish this goal.” Graduate, 28 years old.

"Because of family reasons and time issues I had to drop out from UACM and go to another institution, where I am currently studying a career in International Trade. I go to school on Saturdays and next year I will be done. I studied a Major in Customs Procedures and I am also learning English in IPN ${ }^{15}$ " Student, 26 years old.

"Of course my main objective is to get my degree. But I have not been able to complete my studies because of family issues. I am trying to write my dissertation, but I truly believe I am not doing things right, I get stuck a lot. Unfortunately, I get constantly reminded that my employers need my certificate and official documents.” Graduate, 30 years old.

\section{Group 3:}

"I need to pass the eight subjects I still have pending and write my dissertation. I have been in school for five years and I have not finished yet. I am putting all my effort to reach this objective." Adult in college, 50 years old.

"I am writing my dissertation." Adult in college, 48 years old.

"I still owe seven courses: Language and Thinking, Political Theory 1 and 2, English 2 and 3, Government Branches and Large-Scale Issues of Mexico City. I am doing research for my thesis and working.". Adult in college, 41 years old.

\footnotetext{
15 Instituto Politécnico Nacional (IPN).
} 
Artigo Original

Hegemonia - Revista Eletrônica do Programa de Mestrado em Direitos Humanos, Cidadania e Violência/Ciência Política do Centro Universitário Unieuro

ISSN: $1809-1261$

UNIEURO, Brasília, número 27 (Especial), 2019, pp. 215-244.

\section{Discussion}

The difficulty in identifying educational resilience within the concepts of marginality, economic marginalization and capability poverty is to be compensated by presenting the set of answers of each group in blocks.

Why is educational resilience important? Students display uneven changes as a result of having attended college. Changes are evident in some of them, but not very clear in others. The educational model allows students to enroll in courses of their choice; however, there are some recommendations to move forward according to the program. I present educational resilience as the emotional ability to overcome obstacles and make progress in higher-level academic achievement strengthens the feeling of self-worth, which is observable in the skill for concluding a dissertation project and defending it in an academic environment.

Out of the six students that hold the degree, four of them graduated with honors. The emotional support received by each graduate (man and woman) was different. In two of the professional examinations the student was accompanied by both parents; the rest of them were as follows: one was accompanied by the mother only, other by one sibling, the other one by the mother and a sibling, and other by daughter. I suggest to locate the educational resilience of the yin and yan components that Baruch and Stutman state (2008; 61), thus, the educational resilience as the ability to decide and the emotional capacity to perform, has a yin dose. Educational resilience as a skill and emotional ability has a dose of yin (that person makes you feel valuable and he/she trusts your decisions), and a dose of yang (the difficulties that help you overcome adverse events); the balance between the two helps to make progress in academic life and complete the school cycle. The ability to develop resilient potential is fundamental, as it makes it easier to leave marginality and capability poverty behind.

Based on the results of this research, and the students ability to decide changing patterns, the following model is proposed, 


\section{Artigo Original}

Hegemonia - Revista Eletrônica do Programa de Mestrado em Direitos Humanos, Cidadania e Violência/Ciência Política do Centro Universitário Unieuro

ISSN: $1809-1261$

UNIEURO, Brasília, número 27 (Especial), 2019, pp. 215-244.

Table 1

RESILIENT ABILITY

\begin{tabular}{|c|c|c|}
\hline Resources & Marginality & $\begin{array}{c}\text { Educational } \\
\text { Resilience }\end{array}$ \\
\hline I AM & Low/High & High/Low \\
\hline I HAVE & Low/High & High/Low \\
\hline I CAN & Low/High & High/Low \\
\hline
\end{tabular}

Prepared by author.

The self-determination to change and to become responsible of each choice, makes the probability flexible: high marginality and high educational resilience. The 'I am', 'I have', and 'I can' resources are part of the $\mathrm{X}$ axis (independent variables), whereas the mental and emotional elements of marginality and educational resilience make up the $\mathrm{Y}$ axis (dependent variable). The closer they get to zero, the less resilience the student has. All values higher than zero represent a certain degree of educational resilience. On the contrary, negative values represent selfsabotage and destructive decisions.

\section{Final Considerations}

Interviewees showed clarity when defining their lives five years from now; nonetheless, their ability to continue moving forward despite adversity goes against their expectations and their own professional life design.

If poverty is multidimensional, how can capability poverty elements be observed in a student population? How do you identify severe deprivations to welfare that prevent college students to "have and be what they rationally consider is worth having and being" (Mora, 2010: 17)? Marginalization supposes a barrier to the values and behaviors of modern man (Cortés, 2006: 75). Waging for a change in mindset that focuses on handling emotions adequately is basic for dealing with marginalization and capability poverty. Joining a formal higher education system 
Artigo Original

Hegemonia - Revista Eletrônica do Programa de Mestrado em Direitos Humanos, Cidadania e Violência/Ciência Política do Centro Universitário Unieuro

ISSN: $1809-1261$

UNIEURO, Brasília, número 27 (Especial), 2019, pp. 215-244.

can have an impact on this, but it will not determine the change in beliefs. In parallel, it transforms the marginalization situation.

The limit between social networks in marginalized populations and the social capital in exclusion intersect in capability poverty. The educational bet does not necessarily provide students with the necessary elements to overcome obstacles by handling emotions. The educational resilience potential is a personal decision from the present, form now to break all patterns the reproduce themselves. I propose the educationa resilience concept as the emotional capacity to choose a different prifessional life path, that allows to overcome the capabilities poverty of the population living in marginality experiences. I take the I am, I have, and I can categories back in their yin and yan doses to visualize these components in the personal decision making, that allow to overcome the capabilities poverty from the educational discipline and the value to transform their professional present, overcoming adverse contexts. Changing the now from the emotional roots to "commit to a task until completing it" and to have "the clarity to plan the future" (Henderson, 2008: 28). The emotional that connects with the academic rationality.

All students who participated in the qualitative phase stated that they studied to improve their life quality. The dissertation process to obtain the degree poses a possibility to foster the feeling of self-worth, which concurrently increases the strength to face adversity in family contexts where there has been a lack of higher education. Confronting possible rejection could explain the low rate of degree obtention. The ability and emotional decision to overcome obstacles translates into personal freedom; it reinforces the 'I have', 'I am', and 'I can' element. 
Hegemonia - Revista Eletrônica do Programa de Mestrado em Direitos Humanos, Cidadania e Violência/Ciência Política do Centro Universitário Unieuro

ISSN: 1809-1261

UNIEURO, Brasília, número 27 (Especial), 2019, pp. 215-244.

Annex

$$
\text { Survey on UACM Study Process at Bachelor's Degree Level }
$$

Age: $\quad$ Do you have children? (How many? Ages?):

Motivation

1. Was UACM your first choice for higher education?

2. Why did you decide to study at UACM?

3. What did you do before attending UACM?

4. Did you drop out of school at some point? What prevented you from studying before?

Expectations

5. What results do you expect to see in your life by having a college degree? Why are you studying a career? What do you seek to achieve? What are you doing to reach your goal?

Experience in University

6. Did you like working in teams or individually?

7. Did you understand all the texts in your courses? Which was the hardest subject and which one the easiest?

8. ¿Who were your best friends? Did you know them before joining UACM?

On Academic Results

9. Have you obtained your degree? How long did it take you to get your degree once you completed your courses with $100 \%$ of the credits?

10. Do you owe courses? How many and which ones?

11. What do you have pending?

12. Are you planning to do it? What is stopping you?

13. Are you planning on getting the degree or just completing the academic credits?

14. ¿What results are you expecting from obtaining the degree?

15. ¿What are you doing to obtain it? 
Artigo Original

Hegemonia - Revista Eletrônica do Programa de Mestrado em Direitos Humanos, Cidadania e Violência/Ciência Política do Centro Universitário Unieuro

ISSN: 1809-1261

UNIEURO, Brasília, número 27 (Especial), 2019, pp. 215-244.

16. How do you see yourself in five years? 
Artigo Original

Hegemonia - Revista Eletrônica do Programa de Mestrado em Direitos Humanos, Cidadania e Violência/Ciência Política do Centro Universitário Unieuro

ISSN: $1809-1261$

UNIEURO, Brasília, número 27 (Especial), 2019, pp. 215-244.

Bibliography

Gobierno de la Ciudad de México (2001), Administración Pública del Distrito Federal, Gaceta Oficial del Distrito Federal, México.

Baruch Rhoda y Suzanne Stutman (2008), "El yin y el yang de la resiliencia”, en Edith Henderson Grotberg, La resiliencia en el mundo de hoy. Cómo superar las adversidades, Argentina, Gedisa Editores, pp. 59-90.

CONAPO (2010), Anexo B Marginación urbana por entidad federativa y municipios, México, Consejo Nacional de Población, en: http://www.conapo.gob.mx/work/models/CONAPO/indices_margina/marginacion_urbana /AnexoB/Documento/05B_AGEB.pdf (27 de marzo de 2016).

CONEVAL (2011), Medición de pobreza en los municipios de México 2010, México, Consejo Nacional de Evaluación de la Política de Desarrollo Social, en: http://www.coneval.org.mx/informes/Pobreza/Pobreza_municipal/Presentacion/Pobreza_ municipios.pdf (27 de marzo de 2016).

Cortés, Fernando (2006), “Consideraciones sobre la marginación, la marginalidad, marginalidad económica y exclusión social", Papeles de Población, vol. 12 núm. 47 enero-marzo, Universidad Autónoma del Estado de México, México, pp. 71-84.

Henderson Grotberg, Edith (2008), “¿Qué entendemos por resiliencia? ¿Cómo promoverla? ¿Cómo utilizarla?, en Edith Henderson Grotberg, La resiliencia en el mundo de hoy. Cómo superar las adversidades, Argentina, Gedisa Editores, pp. 17-57.

Isunza Vizuet, Georgina y Benjamín Méndez Bahena (2011), "Desarrollo inmobiliario y gobiernos locales en la periferia de la Ciudad de México”, EURE, vol. 37 núm. 111 mayo, Pontificia Universidad Católica de Chile, Chile, pp. 107-129.

Gobierno de la Ciudad de México (2005), Ley de la Universidad Autónoma de la Ciudad de México, México, Gaceta Oficial del Distrito Federal. 
Artigo Original

Hegemonia - Revista Eletrônica do Programa de Mestrado em Direitos Humanos, Cidadania e Violência/Ciência Política do Centro Universitário Unieuro

ISSN: $1809-1261$

UNIEURO, Brasília, número 27 (Especial), 2019, pp. 215-244.

Mora Santos, Minor (2010), "El desafío del análisis multidimensional de la pobreza", en Julio Boltvinik y otros (coordinadores), Medición multidimensional de la pobreza en México, México, El Colegio de México- Consejo Nacional de Evaluación de la Política de Desarrollo Social, pp. 1141.

Sen, Amartya (2000), Desarrollo y Libertad, Buenos Aires, Edit. Planeta.

SIDESO (2000), Sistema de Información de Desarrollo Social Perfil Sociodemográfico y grado de marginación por Unidad Territorial, México, Jefatura de Gobierno del Distrito Federal, Coordinación de Planeación del Desarrollo Territorial, en: http://www.sideso.df.gob.mx/documentos/ut/IZP_07-091-1_C.pdf (18 de julio de 2016).

SIDESO (2000), Sistema de Información de Desarrollo Social Perfil Sociodemográfico y grado de marginación por Unidad Territorial, México, Jefatura de Gobierno del Distrito Federal, Coordinación de Planeación del Desarrollo Territorial, en: http://www.sideso.df.gob.mx/documentos/ut/IZP_07-089-1_C.pdf (18 de julio de 2016).

SIDESO (2000), Sistema de Información de Desarrollo Social Perfil Sociodemográfico y grado de marginación por Unidad Territorial, México, Jefatura de Gobierno del Distrito Federal, Coordinación de Planeación del Desarrollo Territorial, en: http://www.sideso.df.gob.mx/documentos/ut/GAM_05-077-1_C.pdf (18 de julio de 2016).

STPS (2016a), Clasificación de municipios por área geográfica, México, Secretaría del Trabajo y Previsión Social, en: http://www.conasami.gob.mx/pdf/estructura\%20municipal/nueva_area_geografica_A/DIST RITO\%20FEDERAL.pdf (18 de julio de 2016).

STPS (2016b), Salarios minimos generales por áreas geográficas 1996-2016, México, Secretaría del Trabajo y $\quad$ Previsión en: http://www.conasami.gob.mx/pdf/salario_minimo/2016/salarios_area_geo_2016.pdf (18 de julio de 2016). 
Artigo Original

Hegemonia - Revista Eletrônica do Programa de Mestrado em Direitos Humanos, Cidadania e Violência/Ciência Política do Centro Universitário Unieuro

ISSN: $1809-1261$

UNIEURO, Brasília, número 27 (Especial), 2019, pp. 215-244.

Universidad Autónoma de la Ciudad de México (2013), Ley de la Universidad Autónoma de la Ciudad de México, México, Impreso en los talleres de la Universidad Autónoma de la Ciudad de México.

Universidad Autónoma de la Ciudad de México (2008), Perfil del estudiante de la UACM generación 2005-I, México, Universidad Autónoma de la Ciudad de México.

Universidad Autónoma de la Ciudad de México (2012), Perfil del estudiante de la UACM generación 2010, México, Universidad Autónoma de la Ciudad de México.

Universidad Autónoma de la Ciudad de México (2015), Base de datos generación 2015, México, Universidad Autónoma de la Ciudad de México.

Vázquez Sandoval, Martín (2012), “La crisis económica y la formación de la UACM”, en María del Carmen Díaz Vázquez (Coord.), El ciclo básico y el proyecto educativo en la UACM. Un estudio interdisciplinario, Editores Universidad Autónoma de la Ciudad de México e Instituto de Ciencia y Tecnología del Distrito Federal, México. 